OPEN ACCESS

Citation: Angelo Gaudio (2021) Giovanni Gozzer and the reform of secondary schools in Italy during the Seventies. Rivista di Storia dell'Educazione 8(1): 61-69. doi: 10.36253/rse-10362

Received: January 21, 2021

Accepted: March 1, 2021

Published: July 5, 2021

Copyright: (c) 2021 Angelo Gaudio. This is an open access, peer-reviewed article published by Firenze University Press (http://www.fupress.com/rse) and distributed under the terms of the Creative Commons Attribution License, which permits unrestricted use, distribution, and reproduction in any medium, provided the original author and source are credited.

Data Availability Statement: All relevant data are within the paper and its Supporting Information files.

Competing Interests: The Author(s) declare(s) no conflict of interest.

Editor: Martino Negri, Università di Milano-Bicocca.

\section{Giovanni Gozzer and the reform of secondary schools in Italy during the Seventies ${ }^{1}$}

\section{Giovanni Gozzer e la riforma della scuola secondaria in Italia negli anni Settanta}

\author{
Angelo Gaudio \\ Università di Udine \\ E-mail: angelo.gaudio@uniud.it
}

\begin{abstract}
This article deals with the role played by Giovanni Gozzer in opposition to the secondary school reform in Italy during the second half of the Seventies. Drawing on the arguments of the international debate, which he knew in great detail, he defended the ongoing middle school reforms of 1962 but opposed the proposals for the secondary school reforms, considering them to be promoted principally by the communist party which even seemed to succeed in holding sway over the left-wing reformist Christian democrats.
\end{abstract}

Keywords: Giovanni Gozzer, comparative education, secondary school system, Twentieth century, Italy, Seventies.

Riassunto. Questo articolo tratta del ruolo svolto da Giovanni Gozzer nellopposizione alla riforma della scuola secondaria in Italia nella seconda metà degli anni Settanta. Attingendo agli argomenti del dibattito internazionale che conosceva con grande profondità, si oppose alle riforme scolastiche in corso. Gozzer difende la riforma della scuola media del 1962, ma si oppone alle proposte di riforme della scuola superiore ritenendola principalmente promossa dal Partito comunista che sembrava riuscire a egemonizzare anche la sinistra democristiana riformatrice.

Parole chiave: Giovanni Gozzer, educazione comparata, scuola superiore, XX sec., Italia, anni Settanta. ${ }^{1}$

\footnotetext{
${ }^{1}$ The present article develops some aspects of a previous and shorter contribution presented by the author, entitled "The Difficult Internationalization of Italian Education Discourse. The Case of Giovanni Gozzer 1974-1980", in Tranferencia, transnationalization y transformación de las politicas educativas (1945-2018), ed. Mariano González-Delgado, Manuel Ferraz Lorenzo, and Christian Machado-Trujillo. Cabrerizos, Salamanca: Fahrenhouse, 85-90 (Book of abstracts for the Simposio internacional, June 3-5, 2020, University of La Laguna, Tenerife, Spain. The conference has been delayed to 2021 because of the pandemic).
} 
The role of Giovanni Gozzer (1915-2006) in the context of the Italian reception of the global public discourse on the relationships between education and economic development has been already investigated in previous studies (Gaudio 2018; Todaro 2020). Giovanni Gozzer graduated in humanities from the Catholic University of the Sacred Heart (Milan) to then become a teacher in the secondary schools of Trento. After the liberation of the province of Trento, in 1945 he became provisional local education superintendent (provveditore agli studi) on the basis of the joint designation of the allied military government and the National Liberation Committee (Comitato di Liberazione Nazionale, CLN) of Trento, of which he became president. In 1947 he attended the Piaget courses in Geneva. In 1948 he began to collaborate with the Italian minister of public education, Guido Gonella, as secretary of the School Reform Inquiry Commission. From 1959 to 1972, Gozzer was director of the Frascati European Education Centre, a government institution and agency for teachers' lifelong learning. He headed the Section of studies of the Department of Education from 1962 to 1963 and from 1970 to 1972 . He carried out important investigations and consultancy missions for UNESCO in Spain and Latin America. His most significant works include I cattolici e la scuola (Catholics and School, 1964), Programmazione scolastica e sistemi educativi. La pedagogia (School Programmes and Educational Systems. Pedagogy, 1970), and the Rapporto sulla secondaria: la riforma degli istituti secondari superiori nel dibattito politico e culturale dal 1950 al 1973 (Secondary School Report: the Reform of the Secondary School Institutions in the Political and Cultural Debate from 1953 to 1970, 1973).

Formally a civil servant as a school principal, he performed the role of high counsellor for several ministers, from Guido Gonella in the late Forties to Oscar Luigi Scalfaro in the early Seventies, thanks to his proximity to the powerful Catholic Middle School Teachers Association. This role was of particular importance in drawing up the middle school reform of 1962.

In the last part of his life, after his retirement, he played a relevant role as a writer. While Gozzer's writings about the international debate in relation to the Italian context defend the continuation of the reforms of compulsory education, he argues that it was impossible to modify the systems of secondary education. During this phase of the history of the Italian education system, the very number of transformations and presence of new generations of teachers can be defined as a "change without reform". In this phase, while continuing to make the international education debate known to the Italian public, Gozzer was often one of the most authoritative oppo- nents to the proposals of a comprehensive reform of the secondary schools. It is therefore an interesting case in which the information transfer and political transfer do not coincide.

Beginning in the late Forties, Gozzer repeatedly informed the Italian-speaking public about international educational policies and in particular carried out intense dissemination and lobbying work to sensitize public opinion and stakeholders on the growing links between education and the economic situation. In particular, as a sensitive reforming technocrat, he also approached the Association for the Development of Industry in Southern Italy (Svimez) and Ministry of Education (Mpi) offices to try to introduce school planning methods in Italy. He was the Italian representative at UNESCO and, on behalf of this organization, he carried out important study missions in Colombia and China and above all played an important role in the design of the Spanish law on education reform of 1970 . He also had the opportunity to play a critical role in the Italian debate on the de-scholarization theses proposed by Ivan Illich, which met with great success in Italy, particularly in Catholic circles, arguing that the social division of labour, and therefore the professionalization of teaching, was an unavoidable characteristic of a modern industrial society.

Gozzer's works of this period were published by the Italian publisher Armando, part of the Catholic and liberal milieus which opposed the 1968 reform culture and what they considered the growing submission of the Christian democratic party-led governments to the influence of the leftist political forces, in particular the communist party (Salviati 2009; Zizioli 2011; Pomante and Sani 2013).

On recalling the role played by the publishing house Armando, in an interview from 1997, the same Gozzer defined it as «a place of many comings and goings, but where you met the best brains who had not surrendered to the left-wing climate or the culture of renunciation disguised as a more or less historic compromise» (Antonelli and Arcaini 1997, p. 151).

These orientations developed in circles close to the journalist Indro Montanelli and, on issues specifically concerning schools, around authors such as Vittoria Ronchey, who developed a detailed controversy against those who considered the traditionally centrist parties as succumbing to a "culture of renunciation" (Orlando 1976; Matteucci 1976) to what they considered the growing communist hegemony (Schirripa 2020, forthcoming). These same sensitivities were also significant in key liberal diplomatic circles, which in the same period moved away from Christian democrat politicians with whom they had worked at length, such as Aldo Moro (Gaia 2020). 
There is often a highly comparative approach to the political discourse about education in Italy in the Seventies thanks to an important event: the famous Frascati conference of 1970 (Nuovi indirizzi 1970). Considered the beginning of the secondary school reform project, it was actually a convention of comparative education organized thanks to the Italian representative at the OECD Centre for Educational Research and Innovation (Ceri), Aldo Visalberghi (Corsini 2018). The main report was presented by Stuart Maclure of the Times Educational Supplement (Maclure 2011). This conference is generally associated with the name of the political speaker MP Oddo Biasini, a relatively secondary politician at that time, undersecretary of public education responsible for secondary education, with a solid background as a teacher and then principal. That the conference is perceived as so significant is certainly linked to the words of minister Misasi, who seemed to lean towards a mixture of a comprehensive school reform and a relative $d e-$ scholarization of its professionalizing function,

perhaps it is necessary to imagine that [a teacher's] definitive "specialization" does not take place inside the school but outside the school, assuming a different perspective on issues such as apprenticeships, access to jobs, professional structures at various levels; it will be possible to distinguish the specific activity of professional training from school preparation (Nuovi indirizzi 1970, 14)².

The English scholar, also an authoritative historian and expert of English schools, was aware of the past events and contemporary issues of the Italian school system and hence could predict the political difficulties which the reform would encounter.

One of the main features of the Italian situation is the lack of broad political convergence regarding school reform. A clear school reform policy requires strong political leadership which in turn depends on the clarity of social objectives. Under the present conditions, with governments based on the coalition of political groups and interests, a frank education reform policy is more likely to divide than to unify. And the long-term initiatives it requires - and which could imply a fine-tuning of relations between the church and the State - can only have positive effects on the basis of a broad identity of views. Now, ultimately, education reform is a political responsibility; without the push of a determined political will, in a

\footnotetext{
${ }^{2}$ Original text: «Forse è necessario immaginare che la definitiva specializzazione non avvenga nella scuola ma fuori dalla scuola, assumendo una diversa prospettiva su questioni come apprendistato, accesso all'impiego, articolazione delle professioni ai vari livelli; sarà possibile distinguere le specifiche attività di formazione professionale dalla formazione scolastica».
}

democratic society, changes in school systems and structures will only be slow (Nuovi indirizzi 1970, 18)3.

\section{His prediction was very clear because}

given the widely held opinion among the most advanced scholars that teachers themselves are a conservative force and one of the obstacles to change, the practical and theoretical participation and involvement of teachers in the reform and its implementation will certainly be difficult, but likely to constitute a key point of innovation (Nuovi indirizzi 1970, 39) ${ }^{4}$.

The awareness that teachers tend to hinder or at least slow down any school reform is still part of the most recent and detailed academic pedagogical considerations in Italy (Baldacci 2019, 45). Nevertheless, it is also present in the authoritative views of the international educational discourse (Schleicher 2018). The Italian school system at that time was comparatively very inclusive at middle school level, while at secondary level it was highly channelled and hierarchical. In any case, the long-term effect of the strong growth of the system was democratization and an overcoming of the gender gap (Cappa 2015; OECD 2020).

A volume of Gozzer's published in 1975 offers an extensive review of international documents on education and various Italian publications qualifying, sometimes a little force ably in formal terms, as national reports (Gozzer 1975). In the first chapter of the document titled Il rapporto di Frascati (Frascati Report), it is possible to grasp a first example of Gozzer's rhetorical method which aims to use comparative discourse in order to delegitimize the reforms. Writings which are now considered classics of sociology, such as the works by Marzio Barbagli on intellectual unemployment and

\footnotetext{
${ }^{3}$ Original text: «Una delle caratteristiche principali della situazione italiana è la mancanza di una larga convergenza politica riguardo alla riforma della scuola. Una chiara politica di riforma della scuola richiede una forte guida politica che a sua volta dipende dalla chiarezza degli obiettivi sociali. Nelle presenti condizioni, con governi fondati sulla coalizione di gruppi e interessi politici, una franca riforma dell'istruzione ha più probabilità di dividere che di unificare. E le iniziative di lungo periodo che essa richiede - e che potrebbero certamente implicare una messa a punto delle relazioni tra Chiesa e Stato - potranno avere effetti positivi soltanto in base a una larga identità di vedute. Ora, in ultima analisi, la riforma dell'istruzione è una responsabilità politica; senza la spinta di una decisa volontà politica, in una società democratica, i cambiamenti nei sistemi e nelle strutture della scuola non potranno che essere lenti».

${ }^{4}$ Original text: «Data l'opinione ampiamente diffusa presso gli studiosi più avanzati che gli insegnanti stessi sono una forza conservatrice e uno degli ostacoli per il cambiamento, la partecipazione e il coinvolgimento degli insegnanti alla preparazione pratica e teorica della riforma e della sua esecuzione sarà certamente difficile, ma tale da costituire probabilmente un punto chiave della tecnica dell'innovazione».
} 
the Italian school system (Barbagli 1974/1982) and his anthologies of the sociology of education (Barbagli 1972/1978), were quoted as radical sociological views.

What Gozzer targeted even before the reformist optimism is to be explicitly considered the anthropological optimism behind any reform programme,

the attitudes of the "operators", that is, those who manage the educational systems, are conditioned by different perspectives, which are difficult to alter. A man of the church, cardinal Michele Pellegrino, while speaking of the Council to the Danish journalist Emmanuel Rudbeck, affirmed that, "The Council demands a change of radical mentalities, which is not easy for us with such a different educational background: we can say that this change is difficult for anyone over forty." The same argument applies, and perhaps even more so, in the field of teachers: one can say what one wants but they have been trained as "scholars of a discipline" that they somehow transmit to others. They cannot conceive a global pedagogical vision given their type of educational training, nor, even if they had one, could they apply it to the type of institution in which they operate and the types of services that are required of them (Gozzer 1975, 116-17) ${ }^{5}$.

The classical elitist school model became a sort of "force majeure" behind the possible political decisions, arousing a sort of conservative populism; the pedagogical version of the silent majority embodied in public opinion that had its eponymous hero in the person of Indro Montanelli (Orsina 2015; Ginsborg 1990, 375). These were also aspects that Barbagli had denounced as "vestals of the middle class" (Barbagli 1969), namely teachers linked to the values of a conservative and agrarian culture. Furthermore, the connection between opposition to church reform and opposition to school reform must be underlined; something like Ivan Illich's ideas in reverse.

Gozzer pays special attention to events in the functioning of schools (Gozzer 1980), reformed by the socalled Decreti delegati (Delegated decrees). Adopted in 1974 , they were a combination of the reforms, movements and politics that had developed in those years.

\footnotetext{
${ }^{5}$ Original text: «Gli atteggiamenti degli "operatori" cioè di coloro che gestiscono i sistemi formativi, sono condizionati da prospettive diverse, le quali non possono essere facilmente modificate. Un uomo di Chiesa, il cardinale Michele Pellegrino, parlando del Concilio in un'intervista al giornalista danese Emmanuel Rudbeck, affermò che "Il Concilio chiede un radicale cambio di mentalità radicali, non facili per noi che abbiamo ricevuto una formazione tanto diversa; si può dire che questo cambiamento è difficile per coloro che abbiano più di quarant'anni". Lo stesso argomento vale, e forse a maggior ragione, nel campo degli insegnanti: si può dire quello che si vuole ma essi sono statti formati come "cultori di una disciplina" che, in qualche modo, trasmettono ad altri. Una visione pedagogica globale essi non possono averla, dato il loro tipo di formazione, né potrebbero, avendola, applicarla al tipo di istituzione in cui operano e ai tipi di prestazione che loro sono richiesti».
}

Referring to the discourse by Cascioli (Cascioli 1980), which was based on Social Investments Study Centre (Censis) reports, Gozzer emphasized, with reference to the crisis in participation, that this was a reaction to an excess of expectations, but also that there was still a broad, unspoken potential.

The conclusion takes on the tones of a highly politicized philosophy of history:

The explosive mixture that threatened to completely blow up the scholastic powder keg is therefore in approximately equal parts constituted by the "reactionary" attitude, connected to marxist and socio-utopian populism (the rejection of modernization) and, on the opposite side, the excess of modernization, that is, the introduction to the mixture of the most advanced (and often utopian-futuristic) recipes proposed by socio-scholastic engineering (Gozzer 1980, 126-7) ${ }^{6}$.

The so-called distretto scolastico (school district), the local body, nominally equivalent to a local education authority, was in fact the most innovative element in this mix, proposed as a substitute for the school's desired or actual self-government. It should be noted, however, that much of the debate was focused on the school district (Codignola 1977). For example, the essay by father Ernesto Balducci (Balducci 1974; Paiano 2014) - a Tuscan Piarist and founder of the journal Testimonianze - is a dense and thought-provoking contribution with significant references to Althusser's essay on ideological state apparatuses (Althusser 1970), reflecting on how the school system as a whole could escape the publicprivate dilemma (Gaudio 2011; Pazzaglia 2011) and the role of bourgeois state apparatus. Balducci was a major exponent of progressive Catholic culture, which in those years seemed to have abandoned the old "collaboration" (in Italian defined by the word collateralismo) between the church and christian democratic party and was now irreversibly close to Italian communism (Gerd-Rainer Horn 2001). It is here that the origins and more distant inspirations can be found which led to the laws on the autonomy of schools (Barzanò Grimaldi 2013) and the law on "school parity" (Malizia Cicatelli 2008) towards the end of the Twentieth century.

In 1981, Gozzer offers a contribution in which he discusses the school councils created by the Decreti dele-

\footnotetext{
${ }^{6}$ Original text: «La miscela esplosiva che ha rischiato di far saltare la santabarbara scolastica è dunque in parti approssimativamente uguali costituita dall'atteggiamento "retrivo", collegato al populismo di matrice marxista e socio-utopistica (il rifiuto della modernizzazione) e, sul versante opposto, dall'eccesso di modernizzazione, e cioè l'immissione nella miscela delle ricette più avanzate (e spesso utopistico-avveniristiche) proposte dall'ingegneria socio-scolastica».
} 
gati of 1974 at a meeting of the Council of Europe in the autumn of 1978. In it he presents a report which makes particular reference to the events of the recent school collegial body reforms.

These councils (consigli) go much further than what could be called "opening the school towards the family", as they provide for forms of presence, participation and coresponsibility in the direction and control of the school system by a multiplicity of social forces (political and cultural associations, trade unions, entrepreneurs, etc.). These largely exceed the simple and traditional schoolfamily dimension, outlining profound innovations that involve the very way of thinking about the tasks and purposes of educational structures (Gozzer 1981, 137) ${ }^{7}$.

Inevitably the discussion did not only deal with events of school policy.

The "Italian" case, in this sense, is rather more anomalous than characteristic: countries with traditional open democratic representative systems have not experienced similar advanced and complex systems of the participation and entry into schools of external social realities (Gozzer 1981, 137-138) $)^{8}$.

The exit of Italy from the liberal democracy that the Gozzer feared was also theorized and desired in those years by authoritative exponents of the Italian communist party, for example in the well-known essay by Pietro Ingrao, Masse e potere (Ingrao 1977). What Ingrao saw as an omen, for the educator from Trento became a risk to prevent because,

the impression of the writer of this report is that the "Italian way to participatory management" in schools does not represent the continuance of a long and variously organized effort to make the family component "collaborate" with teachers. Instead, it is the transferral, to a not always decipherable conglomerate of social forces, of tasks once grouped together under State administrative responsibility and control (Gozzer 1981, 139) .

\footnotetext{
${ }^{7}$ Original text: «Tali organismi vanno molto più in là di quella che si potrebbe chiamare "apertura della scuola nei confronti della famiglia", in quanto prevedono forme di presenza, partecipazione e corresponsabilità nella direzione e nel controllo del sistema scolastico da parte di una molteplicità di forze sociali (associazioni politiche e culturali, sindacati, imprenditori, ecc.) che supera largamente al semplice e tradizionale dimensione scolastico-familiare, profilando innovazioni profonde che coinvolgono lo stesso modo di concepire compiti e finalità delle strutture formative».

${ }^{8}$ Original text: «Il caso "Italia", in questo senso, è piuttosto anomalo che caratteristico: non consta che fino a questo momento, nei paesi a tradizionale regime democratico rappresentativo, siano stati realizzati e introdotti sistemi tanto avanzati e complessi di partecipazione e di ingresso nella scuola di realtà sociali esterne».

${ }^{9}$ Original text: «L'impressione dell'estensore del presente rapporto è che
}

Although Gozzer had served as a ministerial official for many years, he formally remained and still considered himself a secondary school principal (Gozzer 1971).

Gozzer showed once again that he was aware of the arguments in radical criticism of the institutions, especially by those who considered schools an institution, but he derived the opposite value judgement; when critics put forward a "scandalous" revelation, the Italian scholar affirmed that there could be no democratic school and that this was a good or at least inevitable thing.

As I have already shown in earlier studies (Gaudio 2018), Gozzer had been one of the many voices in the debate on the theses of Illich, whom he had also known personally at the time of the Council, when the then priest and intellectual was in Rome acting as an expert advisor, following cardinal Suenens (Bruno Joffre Zaldivar 2017; Kaller-Dietrich 2007; Paquot 2011; Illich and Sermonti 2015).

The "common sense" conclusion was that inaction is a virtue. The analysis of the 1968 movement proposed by Gozzer referred to some essays by Domenico Settembrini, a liberal scholar from Pisa who interpreted it as an anti-modern uprising. Behind Gozzer's highest declared inspiration was probably the philosopher Ugo Spirito, one of the main disciples of Giovanni Gentile in Roman academic circles and probably also of the theses of Augusto Del Noce, who denied the theological origins of the alleged collapse of Catholic (Italian) culture in the face of marxism.

It must be stressed that Gozzer questioned the entire sociological discourse on the school as a "power structure". However, he was probably taking aim at the political interpretation of the conflict concerning the school as a power, which could be read in a functionalist light or censured from an anarchist and moralizing point of view. Such a sociological view of education was particularly successful in Italy thanks to the writings of Marzio Barbagli. The Italian case of the halt in the reform of secondary education was attributed to a global reform crisis, to which some of the interventions of Husén referred.

In addition to the volume under study, there was a two-author volume (Gozzer and Valitutti 1978) which examined the reform of secondary education, at the time considered absurd. Salvatore Valitutti (Palladino 2013)

\footnotetext{
la "via italiana alla gestione partecipativa" nella scuola non rappresenti la continuità di un lungo e variamente organizzato sforzo di far "collaborare" la componente familiare con quella insegnante, ma piuttosto il trasferimento, ad un conglomerato non sempre decifrabile, di forze scoiali di compiti un tempo accorpati sotto al responsabilità e il controllo amministrativo-statale».
} 
was a senior official in the public education system and at that time a respected representative of political liberalism as well as the embodiment of the continuity of the State in educational matters. He was one of the most authoritative advocates of the secondary education system that went back to the Gentile reform. Gozzer was the author of the last chapter on secondary education systems in different countries (Great Britain, France, Holland, Denmark, Soviet Union, German Democratic Republic, Poland, Romania, and Hungary), referring mainly to the works of Edmund King (Callegari 2020). The comparative description was used as evidence for a political thesis:

No country in the world (except for the United States, which presents an anomalous model that is difficult to relate to that of other countries) has accepted the principle of the "all-inclusive unitary" school in the secondary system; even where it has been realized (often in fairly recent times), the unity stops at the threshold of compulsory schooling, at the ages of 14,15 or 16, depending on the respective legal systems (Gozzer and Valitutti, 1978, 111) ${ }^{10}$.

A similar comparative argument was put forward by Dino Pieraccioni in 1976 in the columns of the authoritative moderate liberal journal Nuova Antologia (Pieraccioni 1976; Ferrone and Scarlino 2015).

Italy's alleged weakness became the justification for the impossibility of the reform, as emerges from the following lines:

How can we think that a system such as the constitutionally weak Italian one, debilitated by ten years of internal dissolution, can make a leap that no country has managed to realize (or has even hypothesized), is a question we leave the Byzantine theologians of our ambitious "plans" for secondary school reform to answer (Gozzer and Valitutti 1978,134$)^{11}$.

Gozzer himself, incidentally, remained a defender of the 1962 reform and also of its continuation and deepening, implemented with the secondary school pro-

\footnotetext{
${ }^{10}$ Original text: «Nessun paese al mondo (fatta eccezione per gli Stati Uniti, che presentano un modello anomalo difficilmente rapportabile a quello degli altri Paesi) ha accettato o introdotto il principio della scuola "unitaria omnicomprensiva" nel sistema secondario; anche dove essa è stata realizzata (spesso in tempi abbastanza recenti), l'unità si arresta alle soglie della scolarità obbligatoria, ai 14, 15 o 16 anni, a seconda dei rispettivi ordinamenti».

${ }^{11}$ Original text: «Come si possa pensare che un sistema quale quello italiano costituzionalmente debole e dilaniato da dieci anni di dissoluzione interna, possa fare un salto che nessun Paese è riuscito a fare (o non ha neppur ipotizzato), è una domanda che lasciamo per una risposta dei teologi bizantini delle nostre ambiziose "progettazioni" di riforma della scuola secondaria».
}

grammes of 1979 and sanctioning the definitive abolition of Latin as an independent discipline. The reform remained informally part of the academic and ministerial establishment. In 1979 he also cited and anthologized the authors who were part of this kind of expanded establishment, who included not only "technicians" of school evaluation, generally defined as leftist, such as Mario Gattullo and Roberto Maragliano, but also academics of great prestige close to the communist party, such as Tullio De Mauro (Gozzer 1979).

In relation to De Certeau, Gozzer's text began with a questionnaire-based sociological survey of primary school teachers, stressing the tension between the school's cognitive and social function and claiming that it was more appropriate to promote the former (Gozzer 1976, 10).

The fact is that a clear choice is needed: do we want to identify the function of teacher by its socializing or cognitive aspect? However, it must be clear that the socializing choice necessarily requires a precise model of values; unthinkable in a multiple or even conflicting society like the present, divided into many choices of values and behaviours. The socializing choice, more or less cautiously, postulates a total State (I do not mean totalitarian), be it "christian" (in the medieval sense), bourgeois, collectivist or anything else. The cognitive choice is professionally more authentic and liberating; but it requires a professional ability that current generations of teachers are far from possessing (Gozzer 1976, 10) ${ }^{12}$.

Once again, the teacher from Trento was well informed as to the authoritative voices of the global public speech, but drew quite disconcerting conclusions

The school, De Certeau is right, is no longer the "centre of distribution of orthodoxy in matters of social practice"; at best it can be the meeting point (rather than friction point, I would say) of conflicting and contradictory cultural models; but it cannot only be considered the scapegoat for contradictions that society itself cannot heal $(\text { Gozzer 1976, 11) })^{13}$.

${ }^{12}$ Original text: «Il fatto è questo, che occorre una scelta precisa: si vuole identificare la funzione dell'insegnante nell'aspetto socializzante o in quello cognitivo? Deve esser chiaro però che la scelta socializzante esige necessariamente un modello di valori preciso; improponibile in una società come l'attuale, molteplice o addirittura conflittualmente divaricata in molte scelte di valori e di comportamenti, La scelta socializzante, più o meno avvertitamente, postula uno Stato totale (non dico totalitario) sia esso "cristiano" (nel senso medievale), borghese, collettivista o altro. La scelta cognitiva è professionalmente più autentica e liberatrice, ma esige una capacità professionale che le generazioni attuali di insegnanti sono lungi dal possedere».

${ }^{13}$ Original text: «La scuola, ha ragione De Certeau, non è più il centro "distributore dell'ortodossia in materia di pratica sociale"; al massimo può essere il punto di incontro (direi meglio di frizione) di modelli cul- 
The alleged impossibility of the socialization function laid the foundation for this relative de-scholarization which would have marked a progressive shift of the implicit and explicit curriculum from the State to the market, the prophets and mentors of which were those international documents so dear to Gozzer (Gaudio 2016; Malizia 2019; Gaudio 2020). It remains to be seen in what ways views such as those advocated by Gozzer contributed to the halt in secondary education reform projects, at least until the end of the so-called First Republic, but this will be clarified through further research.

\section{SELECTED REFERENCES}

\section{Sources}

Althusser, Louis. 1970. Ideology and Ideological State Apparatuses (Notes towards an Investigation).

«https://www.marxists.org/reference/archive/althusser/1970/ideology.htm)». Accessed March 31, 2020.

Balducci, Ernesto. 1974. "Scuola cattolica e distretto scolastico." Testimonianze 167: 442-476.

Barbagli, Marzio (ed.). 1972. Scuola potere e ideologia. Bologna: Il Mulino.

Barbagli, Marzio. 1974. Disoccupazione intellettuale e sistema scolastico in Italia. Bologna: Il Mulino (Eng. trans. 1982. Educating for unemployment. Politics, labour markets and the school system 1859-1973. New York: Columbia University Press, 1982).

Barbagli, Marzio (ed.). 1978. Istruzione, legittimazione e conflitto. Bologna: Il Mulino.

Barbagli, Marzio, and Marcello Dei. 1969. Le vestali della classe media: ricerca sociologica sugli insegnanti. Bologna: Il Mulino.

Cascioli, Piero. 1980. Il distretto scolastico: proposte operative. Brescia: La Scuola.

Codignola, Tristano. 1977. Il distretto scolastico. Firenze: La Nuova Italia.

Gozzer, Giovanni. 1964. I cattolici e la scuola. Firenze: Vallecchi.

Gozzer, Giovanni. 1970. "Programmazione scolastica e sistemi educativi". In La pedagogia, edited by Luigi Volpicelli. Vol. II. 323-501. Milano: Vallardi.

Gozzer, Giovanni. 1971. Gentile preside. Fossano: Esperienze.

Gozzer, Giovanni. 1973. Rapporto sulla secondaria: la riforma degli istituti secondari superiori nel dibattito

turali conflittuali e contraddittori; ma non può essere considerata solo come il capro espiatorio di contraddizioni che la società non riesce a sanare». politico e culturale dal 1950 al 1973. Roma: Coines.

Gozzer, Giovanni. 1975. Il capitale invisibile: 25 rapporti sulleducazione: 1970-72: la ristrutturazione scolastica, 1973-75: la destrutturazione scolastica. Roma: Armando.

Gozzer, Giovanni. 1976. "Prefazione." In Maestri in Italia: chi sono, cosa pensano, come operano. Rome: Coines.

Gozzer, Giovanni, and Salvatore Valitutti. 1978. La riforma assurda: la scuola secondaria superiore da G. Gentile a M. Di Giesi, edited by Salvatore Valitutti and Giovanni Gozzer. Roma: Armando.

Gozzer, Giovanni (ed.). 1979. I nuovi programmi della scuola media: presentazione e commento. Firenze: Giunti Marzocco.

Gozzer, Giovanni. 1980. Il capitale invisibile: l'epoca dei ripensamenti, 1977-1980. Roma: Armando.

Gozzer Giovanni. 1981. La partecipazione in cammino dal 1910: consigli, collegi, assemblee, comitati nell'iter dei neo-decreti delegati. Rome: Armando.

Ingrao, Pietro. 1977. Masse e potere. Roma: Editori riuniti (Fr. trans. 1980. Masses et pouvoir. Paris: PUF).

Matteucci, Nicola. 1976. Dal populismo al compromesso storico. Roma: Edizioni della voce.

Nuovi indirizzi dell'istruzione secondaria superiore. Atti dell'incontro di esperti convocato dal Governo italiano in collaborazione con l'OCSE-CERI: (Frascati, Villa Falconieri, 4-8 maggio 1970 Centro Europeo dell'Educazione). Frascati: Tipografica Laziale.

Orlando, Federico. 1976. La cultura della resa. Milano: Edizioni dello scorpione.

Pieraccioni, Dino. 1976. "Punti fermi sulla scuola." Nuova Antologia VIII: 530-542.

\section{Critical studies}

Baldacci, Massimo. 2019. La scuola al bivio. Mercato o democrazia?. Milano: Franco Angeli.

Barzanò, Giovanna, and Emiliano Grimaldi. 2013. "Discourses of merit. The hot potato of teacher evaluation in Italy", Journal of Education Policy 28/6: 767-791.

Bottani, Norberto. 1996. "Istruzione e sistemi scolastici. Sociologia", in Enciclopedia delle scienze sociali. Roma: Istituto della Enciclopedia Italiana, vol. V: 134-143.

Brint, Steven. 1998. Schools and Societies. Thousand Oaks: Pine Forge Press (It. trans. 2003. Scuola e società. Bologna: Il Mulino).

Bruno, Joffre, Rosa Zaldivar and Jon Igelmo. 2017. Catholic Education in the Wake of Vatican II. Toronto: University of Toronto Press.

Callegari, Carla. 2020. "Il contributo di Edmund King al rinnovamento dell'educazione comparata italiana 
fra gli anni Sessanta e Settanta", in Autorità in crisi. Scuola, famiglia, società prima e dopo il '68, edited by Tiziana Pironi, 413-421. Canterano (Roma): Aracne.

Cappa, Carlo. 2015. "Italy Transition and Change." In Education in the European Union: Pre-2003 Member States, edited by T. Corner, 201-226. London: Bloomsbury Academic.

Cappa, Carlo. 2018. "Comparative studies in education in Italy. Heritage and transformation." Comparative Education 54/4: 509-529.

Caruso, Marcelo. 2019. "The History of Transnational and Comparative Education." In Handbook of History of Education, edited by John L. Rury and Eileen H. Tamura, 568-588. Oxford: Oxford University Press.

Cellini, Jacopo. 2017. Universalism and Liberation: Italian Catholic Culture and the Idea of International Community, 1963-1978. Leuven: Leuven University Press.

Corsini, Cristiano (ed.). 2018. Rileggere Visalberghi. Roma: Nuova Cultura.

Faggioli, Massimo. 2017. "Vatican II and the governance of the local church: the Diocese of Ferrara, 19591976." In Catholics in the Vatican II Era: Local Histories of a Global Event, edited by Kathleen Sprows Cummings, Timothy Matovina, and Robert A. Orsi Cummings, 226-244. Cambridge: Cambridge University Press. doi:10.1017/9781316493380.012.

Ferrone, Silvano, and Adalberto Scarlino. 2015. La scuola tra classicità e modernità. L'insegnamento di un maestro: Dino Pieraccioni. Firenze: Regione Toscana Consiglio regionale.

Gaia, Roberto. 2020. Console in Libia, edited by Luciano Monzali. Roma: Dante Alighieri.

Gaudio, Angelo. 2011. "Scuole cattoliche e formazione di base." In Cristiani d'Italia. Chiese, Stato e società 1861-2011, edited by Alberto Melloni, 755-766. Roma: Istituto della Enciclopedia italiana.

Gaudio, Angelo. 2016. "Sistemi educativi 2. Democratizzazioni”. In Manuale di Educazione comparata, edited by Nicola Barbieri, Angelo Gaudio, Giuseppe Zago, 187-207. Brescia: LS La Scuola.

Gaudio, Angelo. 2018. “Comparative Education Discourse in Italy After WWII: The Case of Giovanni Gozzer." Rivista di Storia dell'Educazione 5/2: 17-28. doi. org/10.4454/rse.v5i2.163.

Gaudio, Angelo. 2019. L'istruzione secondaria, Manuale di storia della scuola italiana. Dal Risorgimento al XXI secolo, edited by Fulvio De Giorgi, Angelo Gaudio, Fabio Pruneri. Brescia: Scholé.

Gaudio, Angelo. 2020. "La valutazione nel gioco degli specchi comparativi." Scholé. Rivista di educazione e studi culturali 1: 11-26.
Gerd-Rainer, Horn. 2001. Left Catholicism: Catholics and Society at the Point of Liberation in Western Europe, 1943-1955, coedited with Emmanuel Gerard. Leuven: Leuven University Press.

Ginsborg, Paul. 1990. A History of Contemporary Italy: Society and Politics, 1943-1988. London: Penguin Books.

Illich, Ivan, and Vittorio Sermonti. 2015. La cospirazione cristiana nella tirannia della scienza e della tecnica. Firenze: Libreria editrice fiorentina.

Kaller-Dietrich, Martina. 2007. Ivan Illich (1926-2002). Sein Leben, sein Denken, Weitra: Verlag Bibliothek der Provinz, Edition Seidengass (It. trans. 2011. Vita di Ivan Illich: il pensatore del Novecento più necessario e attuale. Rome: Edizioni dell'Asino).

Lemke Duque Carl Antonius, Gasimov, Zaur. 2015. "Transfer \& Translation: Outlines of a Logical Constitutive Model of Cultural Transfer". Comparativ. Zeitschrift für Globalgeschichte und vergleichende Gesellschaftsforschung 25/2: 7-16.

Maclure Stuart [Obituary]. 2011. https://www.tes.com/ news/obituary-stuart-maclure-1926-2011.

Malizia, Guglielmo. 2019. Politiche educative di istruzione e di formazione. Tra descolarizzazione e riscolarizzazione. La dimensione internazionale. Milano: Franco Angeli.

Malizia, Guglielmo, and Sergio Cicatelli. 2011. Catholic School under Scrutiny: Ten Years of Research in Italy (1998-2008). Bern: Peter Lang.

Orsina, Giovanni. 2015. "Liberalism and liberals." In Oxford handbook of Italian politics, edited by Erik Jones and Gianfranco Pasquino. Oxford: Oxford University Press.

OECD 2020, In «https://gpseducation.oecd.org/Country Profile?primaryCountry=ITA». Accessed March 31, 2020.

Paiano, Maria. 2014. "Balducci Ernesto", http://www.treccani.it/enciclopedia/ernesto-balducci_(DizionarioBiografico). Accessed March 31, 2020.

Palladino, Florindo. 2013. "Valitutti Salvatore." In Dizionario biografico dell'educazione 1800-2000, edited by Giorgio Chiosso and Roberto Sani, Vol. II: 621-622. Milano: Bibliografica.

Paquot, Thierry. 2011. "Ivan Illich: politique de l'amitié". Mouvements 4/68: 48-58.

Pazzaglia Luciano. 2011. "I cattolici e la scuola pubblica tra conflitti e partecipazione”. In Cristiani d'Italia. Chiese, Stato e società 1861-2011, edited by Alberto Melloni, 685-700. Roma: Istituto della Enciclopedia Italiana.

Pomante, Luigiaurelio, and Roberto Sani. 2013. "Armando Armando." In Dizionario biografico dell'educazione 
1800-2000, edited by Giorgio Chiosso and Roberto Sani, Vol. I: 63-64. Milano: Bibliografica.

Salviati, Carla Ida. 2009. Una battaglia per la scuola Armando Armando e il «Servizio Informazioni AVIO». Roma: Nuove edizioni romane.

Schleicher, Andreas. 2018. World Class. How to Build a $21^{\text {st }}$ Century School System. Strong Performers and Successful Reformers in Education. Paris: OECD Publishing (It. trans. 2020. Una scuola di prima classe. Come costruire un sistema scolastico per il XXI secolo. Bologna: Il Mulino).

Schirripa, Vincenzo. 2020. La narrativa della scuola disfatta e un suo antecedente del 1975: Figlioli miei, marxisti immaginari, conference Scuole e Maestri nel Mezzogiorno d'Italia tra Ottocento e Novecento. In Scuole e Maestri nel Mezzogiorno d'Italia tra Ottocento e Novecento. Sguardi, problemi e nuovi percorsi di ricerca, edited by Dario De Salvo and Caterina Sindoni, Lecce-Rovato: Pensa Multimedia.

Todaro, Letterio. 2020. “Comparazione, problematicità ideologiche e strategie formative. Uno sguardo sulla dialettica inquieta degli anni Settanta". In Tranferencia, transnationalization y transformación de las politicas educativas (1945-2018), edited by Mariano González-Delgado, Manuel Ferraz Lorenzo, and Christian Machado-Trujillo, 317-328. Cabrerizos, Salamanca: Fahrenhouse.

Zizioli, Elena. 2011. Armando Armando un pedagogista editore. Roma: Anicia. 